\title{
EFFECTS OF POLYCHLORINATED BIPHENYLS ON THE INFECTION OF CHICKENS WITH NON-ONCOGENIC MAREK'S DISEASE VIRUS STRAINS
}

\author{
R. HALOUZKA ${ }^{1}$ AND V. JURAJDA ${ }^{2}$ \\ Department of Pathological Morphology, ${ }^{1}$ Clinic of Avian Diseases, ${ }^{2}$ \\ University of Veterinary and Pharmaceutical Sciences, 61242 Brno
}

Received October 22, 1991

\begin{abstract}
Halouzka, R. and V. Jurajda: Effects of Polychlorinated Biphenyls on the Infection of Chickens with Non-Oncogenic Marek's Disease Virus. Strains. Acta vet. Brno, 61, 1992: 207-217.

The report describes the effects of polychlorinated biphenyls (PCB) on Brown Leghorn chickens infected with non-oncogenic strains ( $M$ and $K$ ) of Marek's disease virus (MDV) and observed during a 5-week period. Two groups of chicks were each infected with $\mathrm{MDV}$ isolates $\mathrm{M}$ and $\mathrm{K}$, respectively, in doses of $10^{3} \mathrm{PFU}$ per bird and fed a non-contaminated feed mixture. Two other groups were infected in the same way and fed the same feed mixture contaminated with PCB at $50 \mathrm{mg}$ per $\mathrm{kg}$ feed. Non-infected chickens fed the non-contaminated feed mixture were used as controls. At weekly intervals the birds were subiected to serological examination and weighed and their lymphoid organs, skin, nerves and gonads were examined histopathologically.

PCB produced apathy, a reduction in body mass, moulting disorders and white discolouration of the feathers. They reduced the production of active MD-precipitating antibody and the incidence of microscopic $\mathrm{MD}$-lymphoproliferative lesions, as compared with the data obtained in the birds only infected. They potentiated cytolytic changes in the lymphoid organs and, at the end of the experiment, caused atrophy of the bursa of Fabricius and of the thymus. Morphological signs of local cell-mediated immunity in the lymphoid organs were observed very rarely.

The results are helpful to the differentiation of morphological immunosuppressive changes of different etiology and contribute to a better understanding of the causes of reduced immunological competence in poultry.
\end{abstract}

Brown Leghorn chickens, polychlorinated biphenyls, non-oncogenic Marek's disease virus, lymphoid organs, immunosuppression

Extraneous substances in the environment, ubiquitous incidence of viral strains of various virulence, and stress are adverse factors which, under certain circumstances, may induce morbid conditions in poultry. They often impair the immune status of the body and the resultant immunomodulation to immunosuppression may be the main factor responsible for polyfactorial diseases and opportune infections or may affect the incidence and course of other pathological processes. It is known, for example, that deliberately induced immunosuppression may induce Marek's disease in vaccinated chickens (Powell and Davison 1986).

In our previous studies (Piskač et al. 1990, Halouzka et al. 1990) dealing with the effects of polychlorinated biphenyls (PCB) on chickens we found marked pathological changes particularly in the lymphoid organs. In another study (Halouzka and Jurajda $1991 \mathrm{a}$ ) we developed morphological criteria for qualitative and quantitative evaluation of regressive changes in the thymus, bursa of Fabricius and spleen. These criteria were used by us in histological examination of cytolytic changes in the lymphoid organs of chickens infected with Marek's disease virus (MDV) strains.

From our experiments (Jurajda and Halouzka 1992b, Halouzka and Jurajda 1992 a) it appears that the pathogenicity of some ubiquitous MDV strains is given also by their immuno- 
suppressive effects. The present study was designed to characterize MD-specific changes and the dynamics of regressive lesions in the lymphoid organs of Brown Leghorn chickens treated experimentally with PCB and infected with non-oncogenic MDV strains.

\section{Materials and Methods}

Two experiments, $M$ and $K$, were carried out with $M D V$ isolates $M$ and $K$ using the same experimental design. The isolation of the two non-oncogenic strains and their in-vitro and in-vivo characteristics were described previously (Jurajda and Halouzka 1992a, b).

The experimental birds were Brown Leghorn chickens (Biggs and Payne 1963).

Each of the two isolates ( $M$ and $\mathrm{K}$ ) wad administered to 2-day old chicks in doses of approximately $10^{3} \mathrm{PFU}$ in $0.2 \mathrm{ml}$ inoculum volumes per bird. The chickens were fed a commercial feed mixture, $\mathrm{K}$, and had water available ad libitum (Group 1).

Equally infected chickens were fed feed mixture K contaminated with PCB in the form of Delor 103 (produced by Chemko Strážske) at $50 \mathrm{mg} . \mathrm{kg}^{-1}$ feed (Group 2).

Non-infected chickens fed non-contaminated feed mixture $\mathrm{K}$ were used as controls (Group $\mathrm{C}$ ).

At 1, 2, 3, 4 and 5 weeks after infection (p. i.) the blood sera were examined for the presence of precipitating antibodies to MDV and the feathers were examined for the presence of precipitating MDV antigen by the method of double immunodiffusion in agar gel as described in a previous report (Jurajda and Halouzka 1992b). The chickens were weighed and sacrificed. At post-mortem examination the bursa of Fabricius and the spleen were weighed. For histological examination tissue samples were taken from the lymphoid organs, peripheral nerves ( $n$. ischiadicus and pl. brachialis), skin and gonads. The tissue samples were fixed in $10 \%$ aqueous solution of formaldehyde, processed using the routine paraffin technique and stained with haematoxylin and eosin and by the Giemsa method.

Cytolytic changes in the lymphoid organs were evaluated quantitatively in immunosuppression (Is) degrees of 0 to 4 and Is index was determined according to morphological criteria as described previously (Halouzka and Jurajda 1991). As MD-specific changes were regarded such lesions as were described by Payne and Biggs (1967).

Relative mass of the bursa of Fabricius and spleen and relative mass index were determined according to Lucio and Hitchner (1979). The results were evaluated in a TNS-Gc computer (AK Slušovice) using programme Abstat at $95 \%$ level of significance and the tables of critical values of mathematical statistics according to Reisenauer (1965). The results of histological examination of the organs were averaged and presented graphically.

\section{Results}

Control non-infected chickens showed no signs of clinical disease and no pathological changes in the organs.

Infected chickens fed the PCB-contaminated feed mixture (Group 2) exhibited apathy, white discolouration and ruffling of the feathers and growth depression from the 4 th week p. i. in both experiments. Post-mortem examination revealed petechial haemorrhages in pelvic limb muscles and mild splenomegaly during the experiment, and marked atrophy of the bursa and thymus in the 5th week p. $i$.

\section{Experiment $M$}

Body mass and relative mass of the bursa of Fabricius and spleen are presented in Table 1.

Passive MD-antibodies were detected in $50 \%$ of the birds in the 1 st week p. $i$. Active MD-antibodies were detected in one bird of Group 1 in the 3rd week p. i. Between the 4th and 5th p. i. week the proportion of chickens with active MD-antibodies increased from $40 \%$ to $70 \%$ of the birds examined. In group 2 the proportion of birds showing active antibodies during the same period was $20 \%$.

The incidence of MD-precipitating antigen in the feathers of Group 1 chickens was detected as early as the 2 nd p. i. week in $20 \%$ of the birds examined. After- 
Table 1

Body mass (in $g$ ) and relative mass of the bursa of Fabricius and spleen of Brown Leghorn chickens afterinfection with $M D V$ isolate $M$ and administration of $P C B$

\begin{tabular}{|c|c|c|c|c|c|c|c|c|c|c|}
\hline \multirow{2}{*}{$\begin{array}{l}\text { Week } \\
\text { p. i. }\end{array}$} & \multirow{2}{*}{ Group } & \multirow{2}{*}{$\begin{array}{l}\text { No. } \\
\text { birds }\end{array}$} & \multirow{2}{*}{$\begin{array}{l}\text { Body } \\
\text { mass } \\
\overline{\mathbf{x}}\end{array}$} & \multirow{2}{*}{ SD } & \multicolumn{6}{|c|}{ Relative mass } \\
\hline & & & & & $\overline{\mathbf{x}}$ & $\begin{array}{l}\text { Bursa of } \\
\text { SD }\end{array}$ & $\begin{array}{l}\text { abricius } \\
\text { Index }\end{array}$ & $\overline{\mathbf{x}}$ & $\mathrm{SD}$ & Index \\
\hline 1st & $\begin{array}{l}C \\
1 \\
2\end{array}$ & $\begin{array}{l}10 \\
10 \\
10\end{array}$ & $\begin{array}{l}54.9 \\
58.6 \\
61.3\end{array}$ & $\begin{array}{r}5.6 \\
11.6 \\
6.7\end{array}$ & $\begin{array}{l}0.168 \\
0.168 \\
0.178\end{array}$ & $\begin{array}{l}0.043 \\
0.037 \\
0.054\end{array}$ & $\begin{array}{l}1.000 \\
0.998 \\
1.058\end{array}$ & $\begin{array}{l}0,072 \\
0.082 \\
0.084\end{array}$ & $\begin{array}{l}0.017 \\
0.028 \\
0.030\end{array}$ & $\begin{array}{l}1.000 \\
1.140 \\
1.167\end{array}$ \\
\hline 2nd & $\begin{array}{l}C \\
1 \\
2\end{array}$ & $\begin{array}{l}10 \\
10 \\
10\end{array}$ & $\begin{array}{l}90.3 \\
94.5 \\
89.7\end{array}$ & $\begin{array}{r}12.0 \\
10.9 \\
9.4\end{array}$ & $\begin{array}{l}0.248 \\
0.228 \\
0.195\end{array}$ & $\begin{array}{l}0.064 \\
0.042 \\
0.036\end{array}$ & $\begin{array}{l}1.000 \\
0.920 \\
0.787\end{array}$ & $\begin{array}{l}0.099 \\
0.150 \\
0.106\end{array}$ & $\begin{array}{l}0.016 \\
0.020 \\
0.020\end{array}$ & $\begin{array}{l}1.000 \\
1.508 \\
1.068\end{array}$ \\
\hline $3 r d$ & $\begin{array}{l}C \\
1 \\
2\end{array}$ & $\begin{array}{r}10 \\
9 \\
10\end{array}$ & $\begin{array}{l}121.1 \\
115.2 \\
120.0\end{array}$ & $\begin{array}{l}20.7 \\
20.3 \\
22.4\end{array}$ & $\begin{array}{l}0.246 \\
0.254 \\
0.246\end{array}$ & $\begin{array}{l}0.046 \\
0.063 \\
0.057\end{array}$ & $\begin{array}{l}1.000 \\
1.034 \\
1.002\end{array}$ & $\begin{array}{l}0.123 \\
0.169 \\
0.148\end{array}$ & $\begin{array}{l}0.025 \\
0.038 \\
0.048\end{array}$ & $\begin{array}{l}1.000 \\
1.371 \\
1.234\end{array}$ \\
\hline 4th & $\begin{array}{l}C \\
1 \\
2\end{array}$ & $\begin{array}{l}5 \\
5 \\
5\end{array}$ & $\begin{array}{l}195.2 \\
202.6 \\
195.0\end{array}$ & $\begin{array}{l}39.8 \\
35.7 \\
30.3\end{array}$ & $\begin{array}{l}0.242 \\
0.269 \\
0.155\end{array}$ & $\begin{array}{l}0.051 \\
0.053 \\
0.022\end{array}$ & $\begin{array}{l}1.000 \\
1.110 \\
0.641\end{array}$ & $\begin{array}{l}0.154 \\
0.242 \\
0.166\end{array}$ & $\begin{array}{l}0.083 \\
0.087 \\
0.058\end{array}$ & $\begin{array}{l}1.000 \\
1.492 \\
1.075\end{array}$ \\
\hline 5th & $\begin{array}{l}C \\
1 \\
2\end{array}$ & $\begin{array}{r}10 \\
10 \\
5\end{array}$ & $\begin{array}{l}245.0 \\
234.0 \\
169.0\end{array}$ & $\begin{array}{l}61.5 \\
48.5 \\
56.2\end{array}$ & $\begin{array}{l}0.235 \\
0.253 \\
0.090\end{array}$ & $\begin{array}{l}0.061 \\
0.024 \\
0.053\end{array}$ & $\begin{array}{l}1.000 \\
1.073 \\
0.384\end{array}$ & $\begin{array}{l}0.163 \\
0.218 \\
0.173\end{array}$ & $\begin{array}{l}0.040 \\
0.129 \\
0.045\end{array}$ & $\begin{array}{l}1.000 \\
1.332 \\
1.054\end{array}$ \\
\hline
\end{tabular}

SD - standard deviation

$\mathrm{x}$ - mean

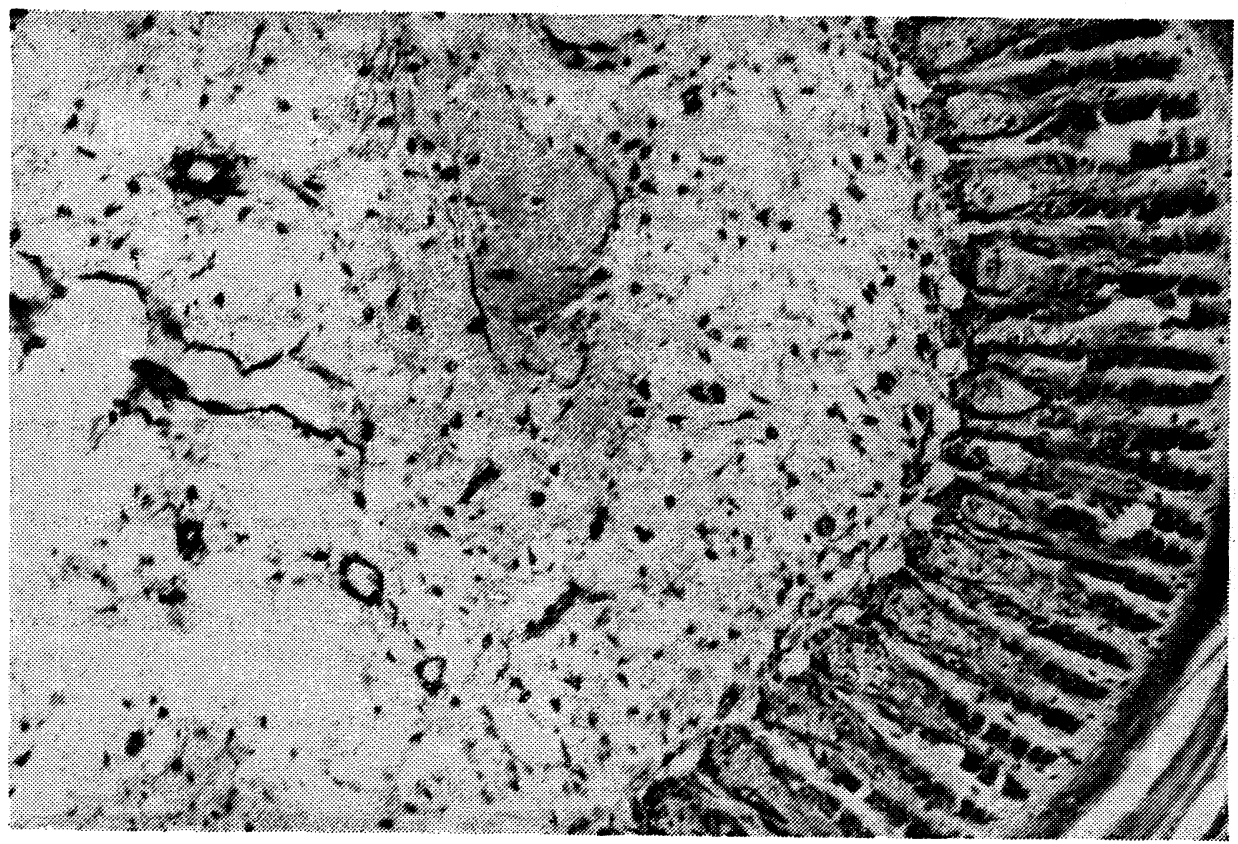

Fig. 1. Degenerative changes in the feather medulla and a decrease of pigment in the epithelial. sheath of a feather follicle. HE $\times 640$. 
wards it rose up to $60 \%$ by the end of the 4 th week and then declined to $40 \%$ in the 5th p. i. week. In Group 2 chickens the incidence of MD-precipitating antigen was found in 1 bird in the 2nd p. i. week and then rose moderately, being detected in $20 \%$ of the birds examined.

Microscopic MD-specific changes were found in $5.8 \%$ of the organs out of 308 examined in Group 1 and in $5.3 \%$ of the organs out of 280 examined in Group 2.

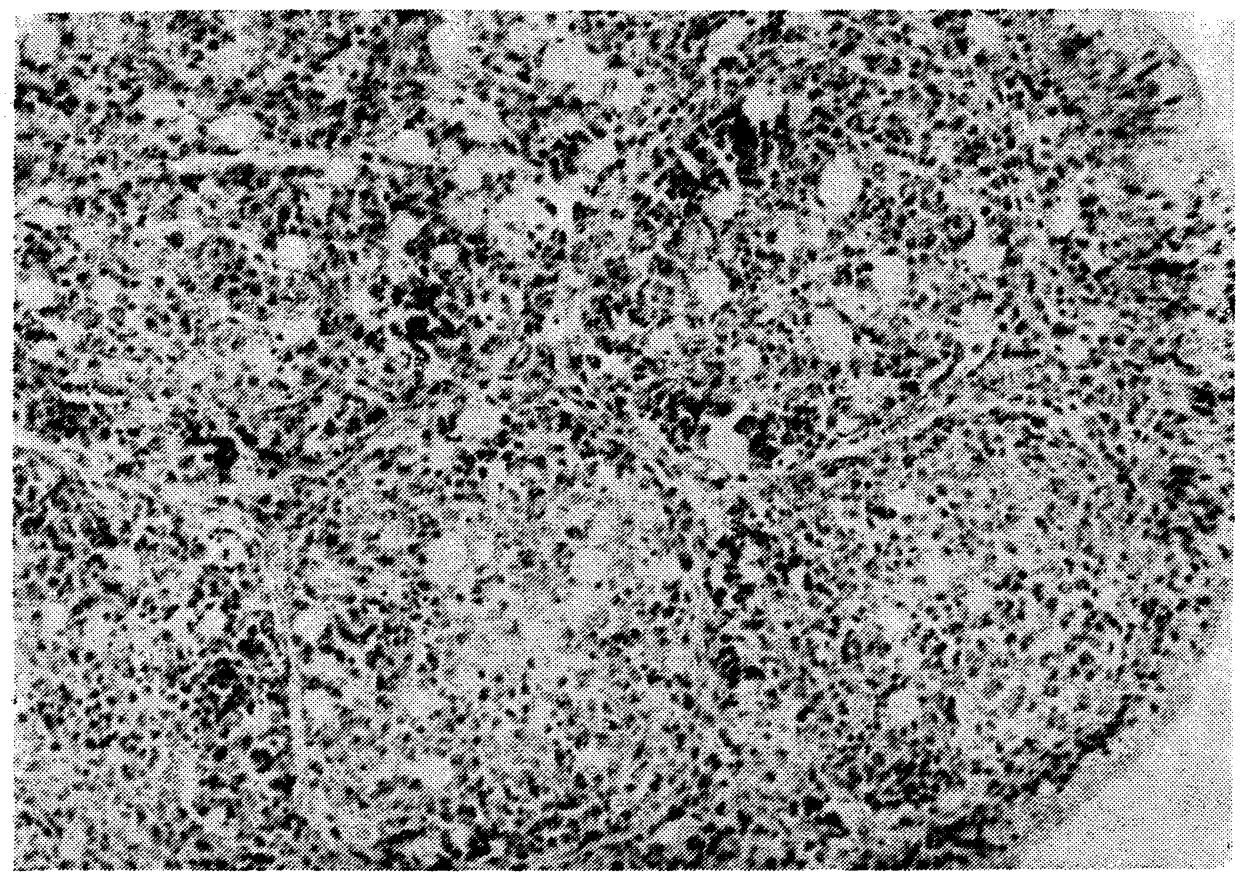

Fig. 2. Cytolysis of lymphocytes and dentritic reticular cells in follicles of the bursa of Fabricius (Is degree 2 ). $\mathrm{HE} \times 640$.

Changes in the skin were characterized by perivascular and perifollicular lymphoid cellulization. Group 2 chickens showed in addition degenerative changes in feather medulla and a decrease of pigment in the cells of epithelial sheaths of feather follicles (Fig. 1). In the nerves these changes were located intraneurally and corresponded to type $\mathrm{C}$ changes. In the testes analogous changes were seen below the tunica albuginea, and in the ovaries they were found in the spongious stroma of the upper cortical layer.

The changes in the germinal centres of the bursa of Fabricius characterized by cytolysis of lymphocytes and dentritic reticular cells were generally classified as Is degree 1 and 2 and occasionally as Is degree 3 (Fig. 2). In Group 2 hardly any syncytial formations, Hassal's corpuscle-like structures and granulomas were found in contrast to granulomas Group 1 chickens where they constituted a regular part of the cytolytic changes. In Group 1 regressive changes in the bursa 


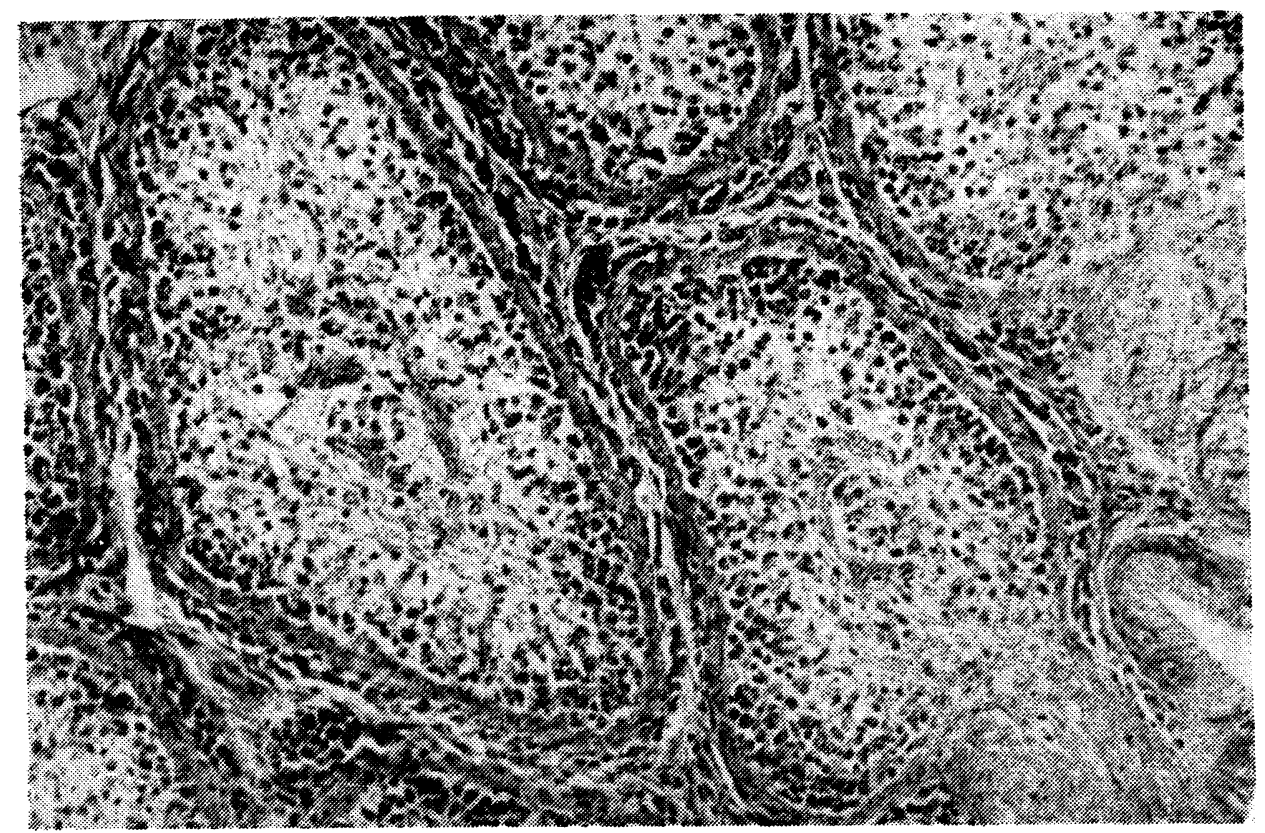

Fig. 3. Atrophy of the bursa of Fabricius (Is degree 4). Interfollicular and intrafollicular fibrosis. $\mathrm{HE} \times 640$.

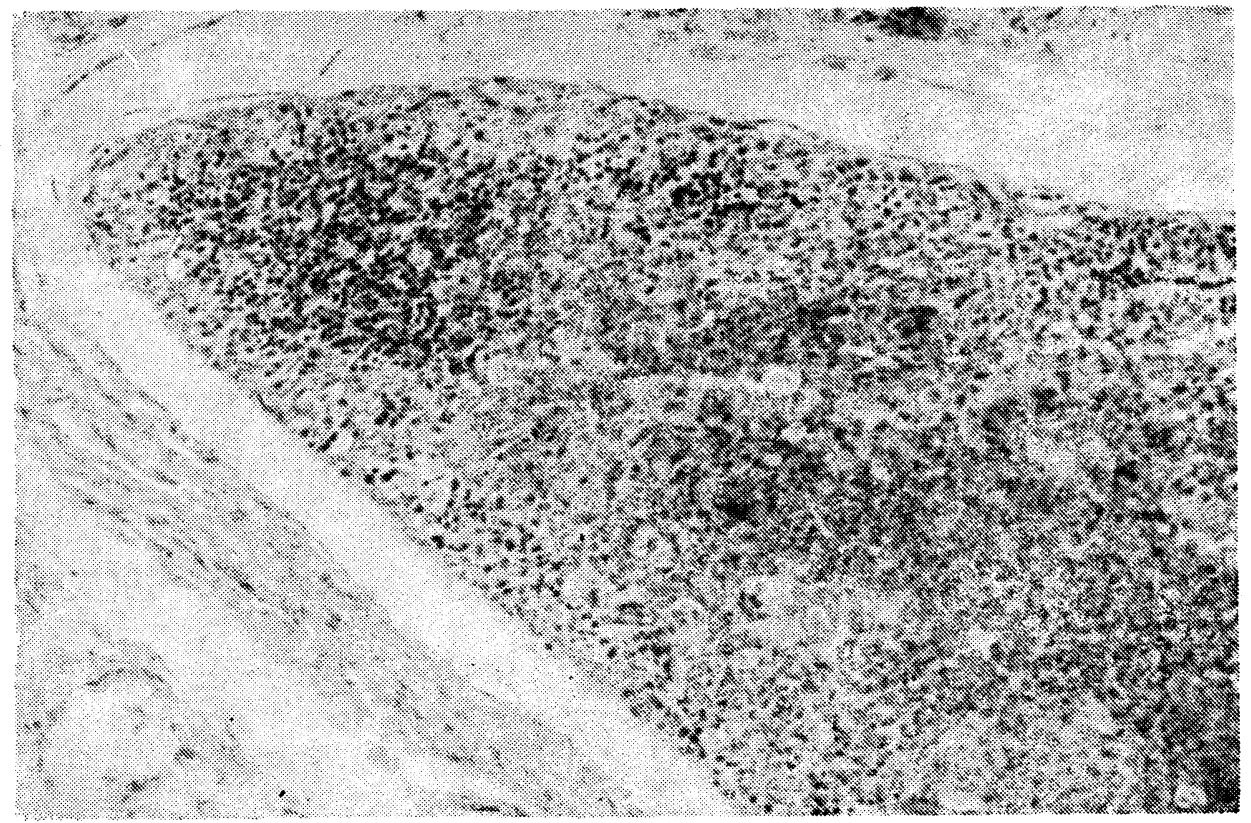

Fig. 4. Atrophy of the thymus (Is degree 4). Lymphocyte depletion of the cortex, infiltration of the medulla. $\mathrm{HE} \times 640$. 
of Fabricius were found 22 times, i. e. in $50 \%$ of the birds, the mean Is index being 0.88 . In Group 2 they were found 28 times, i. e. in $70 \%$ of the birds; the mean Is index was 1.62 with Is degrees 3 and 4 prevailing particularly at the end of the experiment.

Necrosis of lymphocytes and cells of the thymic reticular epithelium with subsequent reduction of the cortex were found 18 times, i. e. in $40.9 \%$ of the birds in Group 1; the mean Is index was 0.78. In Group 2 they were found 17 times, i. e. in $42.5 \%$ of the birds, the mean Is index being 0.88 , and there was no evidence of hypertrophy or hyperplasia of Hassal's corpuscles.

Cytolytic changes in the spleen were less frequent; they were found 7 times i. e. in $15.6 \%$ of the birds in Group 1 , the mean Is index being 0.2 , and 4 times, i. e. in $1 \%$ of the birds, in Group 2 where the mean Is index was 0.3 . In the chickens fed the contaminated feed mixture (Group 2) the congestion of the organ was more conspicuous, whereas in the merely infected chickens (Group 1) proliferation of the reticular elements and cells of the periarteriolar sheaths prevailed.

Out of a total of 132 specimens of the lymphoid organs in Group 1, 47 (35.3\%) showed morphological signs of immunosuppression. In Group 2 these signs were detected in $49(40.8 \%)$ out of 120 specimens examined.

Experiment $\mathrm{K}$

Body mass and relative mass of the bursa of Fabricius and spleen are presented in Table 2.

Passive MD-antibodies were detected in $68 \%$ of the birds in the 1 st week and in $20 \%$ of the birds in the 2 nd week p. i. Neither active MD-antibodiecs nor $\mathrm{MD}$-precipitating antigen were detected in any of the groups.

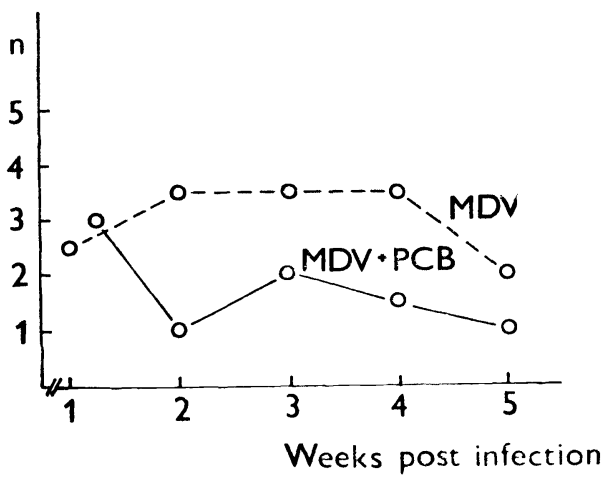

Fig. 5. Number' of "organs of Brown Leghorn chickens showing $\mathrm{MD}$-specific changes after infectionwith MDV isolates and administration of PCB.

Fig. 6. Dynamics of immunosuppressive changes in the central lymphoid organs of Brown Leghorn chickens after infection with MDV isolates and administration of PCB.
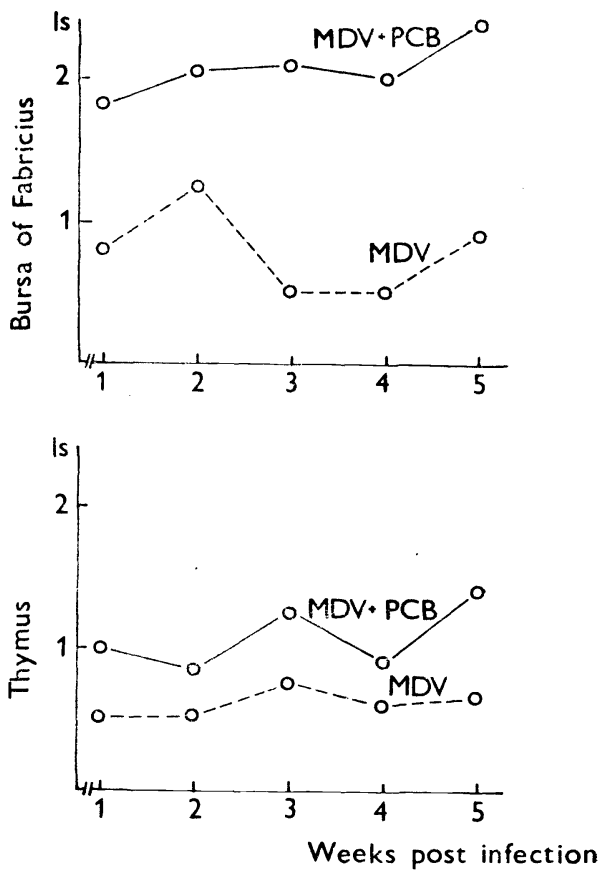
Microscopic MD-specific changes were found in 3.5\% out of 336 organs examined in Group 1 and in $1.1 \%$ out of 175 organs examined in Group 2. Morphologically, the changes were not different from those described in Experiment $M$, except for $M D$-specific pulpitis in feather follicles.

Regressive changes in the central lymphoid organs differed from those observed in Experiment $M$ by higher degrees of immunosuppression.

Cytolytic changes in the bursa of Fabricius were found 23 times, i. e. $47.9 \%$ of the birds, in Group 1 where the mean Is index was 1.24. In Group 2 they were found 24 times, i. e. in $96 \%$ of the birds, the mean Is index being 2.52 (Fig. 3).

In the thymus regressive lesions were detected 15 times, i. e. in $31.2 \%$ of the birds, in Group 1 where the mean Is index was 0.78. In Group 2 they were found 15 times, i. e. in $60 \%$ of the birds, the mean Is index being 1.28 (Fig. 4).

In the spleen these changes were detected 13 times, i. e. in $27 \%$ of the birds examined, in Group 1; the mean Is index was 0.44 . In Group 2 they were found 10 times, i. e. in $40 \%$ of the birds, the mean Is index being 0.88 .

The differences in the morphological changes of the organs between Group 1 and Group 2 were the same as in Experiment $M$.

Out of a total of 144 lymphoid organ specimens examined in Group 1, 51 $(35.2 \%)$ showed morphological signs of immunosuppression. In Group 2 these signs were observed in $49(65.3 \%)$ out of a total of 75 lymphoid organ specimens examined.

\section{Discussion}

The mechanism of the effects of polychlorinated biphenyls is not yet fully understood. Safe and Hutzinger (1987) have reported the main pathological changes due to intoxication with PCB as described by a number of authors in various animal species including poultry with particular reference to their suppres-

Table 2

Body mass (in $\mathrm{g}$ ) and relative mass of the bursa of Fabricius and spleen of Brown Leghorn chickens after infection with $M D V$ isolate $K$ and administration of $P C B$

\begin{tabular}{|c|c|c|c|c|c|c|c|c|c|c|}
\hline \multirow{2}{*}{$\begin{array}{l}\text { Week } \\
\text { p. i. }\end{array}$} & \multirow{2}{*}{ Group } & \multirow{2}{*}{$\begin{array}{l}\text { No. } \\
\text { birds }\end{array}$} & \multirow{2}{*}{$\underset{\overline{\mathbf{x}}}{\text { Body }}$} & \multirow{2}{*}{$\underset{\mathrm{SD}}{\operatorname{mass}}$} & \multicolumn{6}{|c|}{ Relative mass } \\
\hline & & & & & $x^{B u}$ & $\begin{array}{l}\text { of Fabr } \\
\text { SD }\end{array}$ & $\begin{array}{l}\text { ius } \\
\text { Index }\end{array}$ & $\mathbf{x}$ & $\begin{array}{l}\text { Spleen } \\
\text { SD }\end{array}$ & Inde $x$ \\
\hline 1st & $\begin{array}{l}C \\
1 \\
2\end{array}$ & $\begin{array}{r}10 \\
9 \\
5\end{array}$ & $\begin{array}{l}71.1 \\
61.6 \\
61.0\end{array}$ & $\begin{array}{l}5.0 \\
8.2 \\
5.4\end{array}$ & $\begin{array}{l}0.248 \\
0.185 \\
0.162\end{array}$ & $\begin{array}{l}0.059 \\
0.038 \\
0.030\end{array}$ & $\begin{array}{l}1.000 \\
0.747 \\
0.584\end{array}$ & $\begin{array}{l}0.062 \\
0.106 \\
0.078\end{array}$ & $\begin{array}{l}0.012 \\
0.023 \\
0.034\end{array}$ & $\begin{array}{l}1.000 \\
1.710 \\
1.258\end{array}$ \\
\hline 2nd & $\begin{array}{l}C \\
1 \\
2\end{array}$ & $\begin{array}{r}10 \\
10 \\
5\end{array}$ & $\begin{array}{r}104.8 \\
93.9 \\
89.0\end{array}$ & $\begin{array}{l}14.3 \\
12.1 \\
16.0\end{array}$ & $\begin{array}{l}0.227 \\
0.266 \\
0.211\end{array}$ & $\begin{array}{l}0.019 \\
0.056 \\
0.035\end{array}$ & $\begin{array}{l}1.000 \\
1.172 \\
0.928\end{array}$ & $\begin{array}{l}0.076 \\
0.175 \\
0.135\end{array}$ & $\begin{array}{l}0.015 \\
0.047 \\
0.028\end{array}$ & $\begin{array}{l}1.000 \\
2.308 \\
1.773\end{array}$ \\
\hline $3 \mathrm{rd}$ & $\begin{array}{l}C \\
1 \\
2\end{array}$ & $\begin{array}{r}10 \\
9 \\
5\end{array}$ & $\begin{array}{l}136.7 \\
107.2 \\
132.6\end{array}$ & $\begin{array}{l}26.9 \\
21.8 \\
27.0\end{array}$ & $\begin{array}{l}0.276 \\
0.194 \\
0.205\end{array}$ & $\begin{array}{l}0.045 \\
0.066 \\
0.044\end{array}$ & $\begin{array}{l}1.000 \\
0.702 \\
0.742\end{array}$ & $\begin{array}{l}0.125 \\
0.211 \\
0.233\end{array}$ & $\begin{array}{l}0.040 \\
0.099 \\
0.075\end{array}$ & $\begin{array}{l}1.000 \\
1.687 \\
1.864\end{array}$ \\
\hline 4 th & $\begin{array}{l}\mathrm{C} \\
1 \\
2\end{array}$ & $\begin{array}{r}10 \\
10 \\
5\end{array}$ & $\begin{array}{l}201.4 \\
185.0 \\
144.8\end{array}$ & $\begin{array}{l}30.9 \\
34.3 \\
22.0\end{array}$ & $\begin{array}{l}0.323 \\
0.211 \\
0.156\end{array}$ & $\begin{array}{l}0.069 \\
0.066 \\
0.044\end{array}$ & $\begin{array}{l}1.000 \\
0.655 \\
0.482\end{array}$ & $\begin{array}{l}0.107 \\
0.243 \\
0.238\end{array}$ & $\begin{array}{l}0.021 \\
0.119 \\
0.113\end{array}$ & $\begin{array}{l}1.000 \\
2.267 \\
2.228\end{array}$ \\
\hline 5 th & $\begin{array}{l}C \\
1 \\
2\end{array}$ & $\begin{array}{r}10 \\
10 \\
5\end{array}$ & $\begin{array}{l}295.9 \\
236.7 \\
193.8\end{array}$ & $\begin{array}{l}32.8 \\
35.9 \\
66.2\end{array}$ & $\begin{array}{l}0.290 \\
0.234 \\
0.177\end{array}$ & $\begin{array}{l}0.065 \\
0.075 \\
0.060\end{array}$ & $\begin{array}{l}1.000 \\
0.806 \\
0.610\end{array}$ & $\begin{array}{l}0.191 \\
0.195 \\
0.206\end{array}$ & $\begin{array}{l}0.081 \\
0.060 \\
0.092\end{array}$ & $\begin{array}{l}1.000 \\
1.022 \\
1.077\end{array}$ \\
\hline
\end{tabular}

$S D$ - standard deviation

$x$ - mean 
sor effects on the lymphoid organs of mammals and birds. In our country biological and toxicological properties of PCB were studied, e. g., by Herzig (1984) and Vávrová and Mikulík (1988). The effects of PCB on poultry were investigated by Lillie et al. (1975) and Košutzký et al. (1977, 1979). From all these studies it appears that PCB cumulate in fats and impair protein synthesis, thus exerting particularly marked effects on tissues of a high metabolic index and in growing animals. In our previous studies (Halouzka et al. 1990; Piskač et al. 1990) we found marked cytological changes in the bursa of Fabricius of experimental White Hisex chickens after administration of PCB.

The afore-mentioned data on the biological characteristics of PCB were confirmed in the present study. From the body mass data obtained in our experimental chickens it appears that the infection with MDV isolates alone did not markedly affect their growth performance. A significant growth depression, however, was found in those birds that were infected and fed a PCB-contaminated feed mixture. The depression of growth was particularly marked in the experiment with $\mathrm{MDV}$ isolate $\mathrm{K}$.

The moulting disturbances, white feather discolouration and histological changes observed in the skin can apparently be related to PCB cumulation in the skin and subcutaneous fatty tissue and to decreased lipophilic vitamin level. Cecil et al. (1973) drew attention to PCB-induced degenerative changes in the liver of Japanese quail and rats with a subsequent decrease in their blood vitamin A level. Vávrová and Mikulík (1988) arrived at the same conclusion in young cattle.

The present experiments confirmed our previous observations on the cytolytic effects of PCB on the bursa of Fabricius and thymus. At the dose rate used in our study PCB increased the cytolysis caused by non-oncogenic MDV strains by as much as $50 \%$ and produced a significant decrease in the bursa relative mass. The congestion of the spleen was a consequence of the decrease of lymphoid tissue.

Non-specific changes in the lymphoid organs which arise in the pathogenesis of infection with non-oncogenic MDV strains as a manifestation of local cellular defence (Halouzka and Jurajda 1992b) were only rarely observed after the administration of PCB. This finding is of importance in the differentiation of morphological signs of immunosuppression of different etiology.

In Experiment $M$ regressive changes in the bursa of Fabricius were manifested by a marked decrease (by as much as $50 \%$ ) in the number of chickens with active MD-antibodies. In Experiment $\mathrm{K}$ no decrease in antibody production after administration of PCB occurred because $M D V$ isolate $K$ is characterized by a slower replication cycle and does not induce antibody production until the 5th week p. i. (Jurajda and Halouzka 1992b).

Of particular interest was the decreased incidence of MD-specific changes in the organs of chickens both infected and fed PCB-contaminated feed mixture. However, no correlation in the impact on the individual organs could be found. Non-oncogenic MDV strains induce only slight microscopic lymphoproliferative changes and cause less damage to the lymphatic system than oncogenic strains. They spread through latently infected lymphocytes (viraemia) from lymphoid organs of other tissues and induce the development of lymphoproliferative foci (S chat 1985). As was demonstrated in the present study, PCB produce a marked destruction of lymphocytes in the lymphoid organs, which explains the reduction in the development of MD-lymphoproliferative changes. 
It can be concluded that PCB produced a marked reduction in chicken body mass and, when administered simultaneously with MDV strains, exerted a synergic suppressive effect on the lymphoid organs, caused a marked decrease in the production of active $M D$-precipitating antibodies and reduced the incidence of MD-specific morphological changes in the organs. The reported observations. are of practical value in the search for causes of reduced immunological competence in poultry.

\section{Vliv polychlorovaných bifenylů na infekci kuřat neonkogenními viry Markovy nemoci}

$\mathrm{V}$ průběhu pětitýdenního pokusu jsme sledovali působení polychlorovaných bifenylů (PCB) na kuřata genotypu Brown Leghorn infikovaných neonkogenními kmeny ( $M$ a $\mathrm{K})$ viru Markovy nemoci (MDV). Dvě skupiny kuřat byly infikovány dávkou $10^{3} \mathrm{PFU}$ izolátu $\mathrm{M}$ a $\mathrm{K} M \mathrm{MVV}$ a krmeny nekontaminovaným krmivem, dvě skupiny byly stejně infikovány a krmeny krmivem kontaminovaným $50 \mathrm{mg}$ PCB . $\mathrm{kg}^{-1}$ krmiva. Kuřata neinfikovaná a krmena nekontaminovaným krmivem byla kontrolní. Kuřata byla $\mathrm{v}$ týdenních intervalech sérologicky vyšetřována, vážena a lymfatické orgány, kůže, nervy a gonády byly histopatologicky vyšetřovány.

PCB způsobovaly apatii, snížení tělesné hmotnosti, poruchy přepeřování a bílou diskoloraci peři. Snižovaly tvorbu aktivních MD-precipitačních protilátek a výskyt mikroskopických $\mathrm{MD}$-lymfoproliferativních lézi ve srovnání s kuřaty pouze infikovanými. Potencovaly cytolytické změny lymfatických orgánů a na konci pokusu způsobovaly atrofii Fabriciovy burzy thymu. Morfologické známky místní celulární imunity $\mathrm{v}$ lymfatických orgánech byly ojedinělým jevem.

Zjištěné výsledky mají význam při rozlišování morfologických imunosupresívních změn rưzné etiologie a přispívaji $\mathrm{k}$ objasnění příčin snižené imunologické kompetence drůbeže.

\section{Влияние полихлорированных бифенилов на инфекцию цыплят неонкогенными вирүсами болезни Марека}

В ходе пятинедельного эксперимента проводили исследования воздействия полихлорированных бифенилов (РСB) на цыплята генотипа Браун Легхорн, инфицированные неонкогенными штаммами (М и К) вируса болезни Марека (MDV). Две группы цыплят инфицировали дозой $10^{3}$ PFU изолята $\mathrm{M}$ и $\mathrm{K} \mathrm{MDV}$ и кормили неконтаминированным кормом, две группы инфицировали одинаково и кормили кормом, контаминированным 50 мг РСВ.кг-1 корма. Неинфицированные и питающиеся неконтаминированным кормом иыплята были контрольными. В недельных интервалах цыплят серологически исследовали, взвешивали и проводили гистопатологические исследования лимфатических органов, кожи, нервов и гонад.

PBC вызывали апатию, понижение массы тела, нарушения обмена перьев и их белую дисколорацию. Они понижали образование активных MD-преципитационных антител и наличие микроскопических MD- 
-лимфопролиферативных повреждений по сравнению с просто инфицированными цыплятами. Поддерживали цитологические изменения лимфатических органов и в конце эксперимента они вызывали атрофию фабрициевой сүмки и вилочковой железы. Морфологические признаки местного клеточного иммунитета в лимфатических органах стали единичным явлением.

Значение установленных результатов сводится к различию морфологических иммуносупрессивных изменений разной этиологии и они способствуют объяснению причин пониженной иммүнологической способности птицы.

\section{References}

BIGGS, P. M.-L. N. PAYNE: Transmission experiments with Marek's disease (fowl paralysis). Vet. Rec., 75, 1963: 117-119.

CECIL, H. C. - S. J. HARRIS - J. BITMAN - G. F. FRIES: Polychlorinated biphenyl induced decrease in liver vitamin $\mathrm{A}$ in Japanese quail and rats. Bull. Environ. Contam. Toxicol., 9, 1973: 179-185.

HALOUZKA, R. - J. RUPRICH - A. PISKAČ: Účinek polychlorovaných bifenylù na organismus kuřat: patologické změny orgánů po krátkodobém a dlouhodobém přijmu Deloru 103. Veter. Med. (Praha) 35, 1990: 303-312.

HALOUZKA, R. - V. JURAJDA: Morphological Expression of Immunosuppression in poultry. Acta vet. Brno, 60, 1991 a.

HALOUZKA, R.- V. JURAJDA: Isolation and Study of the Biological Pronerties of Non-Oncogenic Chicken Her es Vir'ses of Marek's Disease. Acta vet. Brno, 61, 1992a: 43-49

HALOUZKA, R.-V. JURAJDA: Non-S ecific Mor hological Changes in the orangs of Chickens Infected Ex zerimentally with Marek's Disease Viruses. Acta vet. Brno, 61, 1992 b: $123-131$

HERZIG, I.: Nutriční faktory v etiologii edémové nemoci drủbeže. Project report, VÚVL Brno, 1984, $42 \mathrm{p}$.

JURAJDA, V. - R. HALOUZKA: Izolace a studium biologických vlastností neonkogenních kuřecích herpesvirů Markovy nemoci. 1. Charakterizace in vitro. Veter. Med. (Praha), 37, 1992a: $531-34$.

JURAJDA, V.-R. HALOUZKA: Izolace a studium biologických vlastností neonkogenních kuřecích herpesvirủ Markovy nemoci. 2. Charakterizace in vivo. Veter. Med. (Praha), 37, 1992 b $535-542$.

KOŠUTZKÝ, J.-O. ADAMEC - E. BOBÁKOVÁ - B. Š̃RNÍKOVÃ: Pokles biologickej účinnosti estrogénov u $\mathrm{F}_{1}$ generácie sliepok exponovaných polychlórovaným bifenylom. Veter. Med. (Praha), 22, 1977: $441-447$.

KOŠUTZKÝ, J. - O. ADAMEC-E. BOBÁKOVÁ-B. ŠÁRNÍKOVÁ: Biologické zmeny $u$ kurčiat $\mathrm{F}_{1}$ generácie od nosníc exponovaných polychlórovaným bifenylom. Živočiš. Výr., 24, 1979: 659-664.

I.ILLIE, R. J. - H. C. CECIL - J. BITMAN - F. FRIES - J. VERRET: Toxicity of certain polychlorinated and polybrominated biphenyls and reproductive efficiency of caged chickens. Poult. Sci., 54, 1975: 1550-1555.

LUCIO, B. - S. B. HITCHNER: Infectious bursal disease emulsified vaccine: effect upon neutralizing-antibody levels in the dam and subsequent protection of the progeny. Avian Dis., 23, 1979: $466-478$.

PAYNE, L. N.-P. M. BIGGS: Studies on Marek's disease. II. Pathogenesis. J. Natl. Cancer Inst., 39, 1967: $281-302$.

PISKAČ, A.-J. RUPRICH - R. HALOUZKA: Účinek polychlórovaných bifenylů (PCB) na organismus kuřat: vliv krátkodobého př́ijmu vysokých dávek Deloru 103 na koncentraci thyroxinu, trijodthyroxinu, sodíku, draslíku a vápníku v krevním séru. Veter. Med. (Praha), 35, 1990: $237-246$.

POWELL, P. C. - T. F. DAVISON: Induction of Marek's disease in vaccinated chickens by treatment with betamethasone or corticosterone. Israel J. Vet. Med., 42, 1986: 73-78.

SCHAT, K. A.: Interactions between Marek's disease virus and the host cell - a review. In: Int. Symp. Marek's disease. B. W. Calnek and J. L. Spencer eds., AAAP Kennett Square PA, 1985: $156-174$. 
REISENAUER, R.: Metody matematické statistiky a jejich aplikace, SNTL Praha, 1965: 169p. SAFE, S. - HUTZINGER, O.: Polychlorinated Biphenyls (PCBs): Mammalian and Environmental Toxicology. In: Envir. Toxin., Ser. 1, Berlin-Heidelberg, Springer-Verlag, 1987: $152 \mathrm{p}$.

VÂVROVÁ, M.-A. MIKULIK: Biologické a toxikologické vlastnosti PCB. Veterinářství, 38, 1988: $560-561$. 